\title{
Morality in Phenomenological Structuralism
}

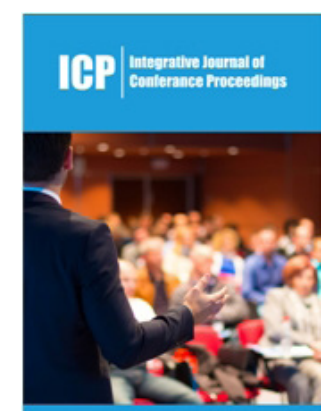

*Corresponding author: Paul C Mocombe, The Mocombeian Foundation, Inc, USA

Submission: 監 May 21, 2019

Published: 想 May 24, 2019

Volume 1 - Issue 3

How to cite this article: Paul C M. Morality in Phenomenological Structuralism. Int J Conf Proc.1(3). ICP.000514.2019.

Copyright@ Paul C Mocombe, This article is distributed under the terms of the Creative Commons Attribution 4.0 International License, which permits unrestricted use and redistribution provided that the original author and source are credited.

\section{Paul C Mocombe*}

USA

\begin{abstract}
This work explores the nature of morality within Paul C Mocombe's structurationist theory of phenomenological structuralism. The author posits that morality or moral standards are associated with the linguistic and ideological desires power and power positions of those who control the resources and mode of production of a material resource framework via their language, ideology, ideological apparatuses, and communicative discourse i.e., social class language game. Its moral practices and statements constitute a part of the superverse/multiverse as phenomenal properties of subatomic particles once disaggregated as lived experience. This does not mean that morality is universal; instead, it is contingent upon the material resource framework and the evolutionary stage of consciousness development as constituted in the framework.
\end{abstract}

Keywords: Structurationism; Praxis; Panpsychism; Social class language game; Phenomenological structuralism; ORCH-OR theory

\section{Introduction}

This work explores the nature of morality within Paul C Mocombe's structurationist theory of phenomenological structuralism. The author posits that morality or moral standards are associated with the linguistic and ideological desires power and power positions of those who control the resources and mode of production of a material resource framework via their language, ideology, ideological apparatuses, and communicative discourse i.e., social class language game. Its moral practices and statements constitute a part of the superverse/ multiverse as phenomenal properties of subatomic particles once disaggregated as lived experience. This does not mean that morality is universal; instead, it is contingent upon the material resource framework and the evolutionary stage of consciousness development as constituted in the framework [1-10].

\section{Background of the problem}

Paul C. Mocombe's 2018, 2019 structurationist theory of phenomenological structuralism, in keeping with the logic of structurationist sociology, assumes practical activity and consciousness, i.e., practical consciousness, to be the basis for understanding human behavior and consciousness in the world. Consciousness here refers to subjective awareness of phenomenal experiences ideology, language, self, feelings, choice, control of voluntary behavior, thoughts, etc. of internal and external worlds and the actions they engender. The academic literature describes three possibilities regarding the origin and place of consciousness in the universe: $A$ as an emergent property of complex brain neuronal computation, B as spiritual quality of the universe, distinct from purely physical actions, and $\mathrm{C}$ as composed of discrete 'proto-conscious' events acting in accordance with physical laws not yet fully understood Hameroff [10]. The latter position, C, represents the ORCH-OR orchestrated objective reduction theory of stuart Hameroff [10], which includes aspects of A and B, and posits that consciousness consists of discrete moments, each an 'orchestrated' quantum-computational process terminated by an action objective reduction or OR, rooted in quantum aspects of the fine structure of space-time geometry, this being coupled to brain neuronal processes via microtubules pg. 70. In this view, the understanding is that a protoconscious experience existed in the universe, panpsychism, and as a result of emergent structures of the brain it proto-conscious experience, psychion became embodied and evolved as a result of quantum neuronal computations of brains [11-25]. 


\section{Theory and Methods}

Paul [26-29] structurationist sociology, phenomenological structuralism, which attempts to resolve the structure/agency problematic of the social sciences, builds on the ORCH-OR theory and panpsychism of Hameroff [10], while holding on to the multiverse hypothesis of quantum mechanics and Haitian ontology/epistemology, which the authors reject because it is not a more down-to-earth view point Hameroff [10]. For Mocombe [26-29] quantum superposition, entanglement, and evidence in Haitian vodou of spirit possession, which represent ancestors from a parallel world, Vilokan, of the earth's of which we ought to pattern our behaviors and structures, are grounding proofs for the acceptance of the multiple worlds hypothesis of quantum mechanics. Within the latter hypothesis, the understanding is that each possibility in a superposition evolves to form its own universe, resulting in an infinite multitude of coexisting 'parallel' worlds. The stream of consciousness of the observer is supposed somehow to 'split', so that there is one in each of the worlds-at least in those worlds for which the observer remains alive and conscious. Each instance of the observer's consciousness experiences a separate independent world and is not directly aware of any of the other worlds Hameroff [10]. It is within this multiple world's hypothesis that Mocombe constitutes the notion of consciousness in the universe according to his theory of phenomenological structuralism. For Mocombe, consciousness is a fifth force of nature, a quantum material substance/energy, psychion, the phenomenal property of which is recycled/entangled/superimposed throughout the multiverse and becomes embodied via the microtubules of brains. It is manifested in simultaneous, entangled, superimposed, and interconnecting evolutionary material resource frameworks as embodied praxis or practical consciousness, which in-turn becomes the phenomenal properties of material subatomic particle energy, psychion consciousness that is recycled/entangled/superimposed throughout the multiverses [30-36].

\section{Discussion and Conclusion}

Hence, as outlined above, phenomenological structuralism posits consciousness to be the by-product or evolution of subatomic particles unfolding with increasing levels of abstraction within an evolutionary material resource framework enframed by the mode of production, language, ideology, ideological apparatuses, and communicative discourse of bodies who control the material resource framework recursively reorganizing and reproducing the ideals of the latter factors as their practical consciousness across entangled/superimposed multiple worlds. They are only conscious of the subjects and objects of only one world at a time, however. Thus, in phenomenological structuralism the understanding is that the structure of reality determines language via its generative grammar and how we ought to live in the multi worlds where consciousness is found. However, the language, and its usage, i.e., social class language game, of those who control the material resource frameworks of the worlds conceal that relationship via their mode of production, ideologies, ideological apparatuses, and communicative discourse, which is evolutionary. In other words, like the Wittgenstein Ian position of the Tractatus, Mocombe's theory of phenomenological structuralism assumes that there is a uniform grammatical structure to language determined by the logical-empirical structure of entangled and superimposed quantum and physical realities. The grammatical structure of linguistic utterances attempts to capture the subjects and objects of those realities and how we ought to live with the subjects and objects in them. In being-in-the-world s with others and objects, this logical-grammatical structure, however, is concealed by the evolution and developmental knowledge, and its usage practical activity, of those who control the material resource framework of the world's via the stage of development of their language, ideology, ideological apparatuses, social relations of production, and communicative discourse. Be that as it may, the latter comes to constitute an evolutionary social class language whose linguistic systemicity and usage comes to determine our conception of reality, and the classes, categories, and forms of life we belong to and interact in and with, which, depending on its stage of development and relation to the True nature of reality as such, is either accepted or constantly deferred by those in its speech community who are marginalized or not represented in its evolutionarily developed linguistic systemicity. The latter process, language usage, under the guise language game, language as a tool, is what Wittgenstein captures in his second treatise on language as developed in the philosophical investigations. That is, the classes and categories created by the dominant social class language game of a material resource framework, in their efforts to capture the subjects, objects, and activities of the logical-grammatical structure of reality and how we ought to live within it, constitute reified classes, categories, and forms of life, language games, whose meanings and praxes as defined by the dominant social class language game are either accepted or deferred by those classified in them. The latter may inturn seek to reify their form of life that they are marginalized for, or categorized in, as a distinct alternative practical consciousness to that of the dominant order thereby undermining the attempted universality of the logical-grammatical structure of the dominant order for notions of diversity, intersectionality, etc.

So, in Mocombe's theory of phenomenological structuralism, Wittgenstein's two theories of language and meaning must be read as one philosophy as opposed to two, one supported by analytical philosophy and the other by postmodernism/post-structuralism. We have a plethora of language games classes, forms of life, and categories in the world, which structures our language, because of the ability to defer meaning in ego-centered communicative discourse and the developmental stage of the human mind and body vis-à-vis the actual True structure of reality. The language of science, like its predecessor religion, attempts to capture the logical-empirical structure of quantum and physical reality, and how we ought to live within it, amidst the utterances and practical consciousnesses of the masses given their abilities to defer meaning in ego-centered communicative discourse and the classes, categories, and forms of life they are classed in/with by the dominant social class language game as they attempt to capture the overall nature of reality via language. 
Hence within the theory and methodology of phenomenological structuralism, there is, contrary to David Hume's bundle of perception hypothesis, a human essence, which is tied to the embodiment and structuring structure of the phenomenal properties of superimposed, entangled, embodied, and recycled subatomic particles, the processes of which are unbeknownst to us as of the writing of this work, as they are recursively reorganized and reproduced via the superverse and its multiverses. Just the same, universalism and truth are also tied to the science and physics of the remaining processes of phenomenological structuralism. Subatomic/chemical particles with phenomenal properties constitute objects and subjects that are external and internal to the perceiving human actor who know them the objects and subjects as both external and internal phenomenon endowed with, and mediated by, linguistic and ideological meanings, stemming from the evolutionary modes of production, of other human actors who presupposed their aggregated existence. The essence, universalism, and truth of an object and subject lies in the phenomenal properties of their subatomic and chemical particles once demystified and demythologized, from linguistic and ideological meanings and understandings associated with the evolutionary mode of human production, by the techniques of phenomenology and the scientific process. Be that as it may, for phenomenological structuralism, in keeping somewhat with the empiricist logic of Bertrand Russell, outside of human desires there are no moral standards.

Morality or moral standards are associated with the linguistic and ideological desires power and power positions of those who control the resources and mode of production of a material resource framework via their language, ideology, ideological apparatuses, and communicative discourse i.e., social class language game. Its moral practices and statements constitute a part of the superverse/multiverse as phenomenal properties of subatomic particles once disaggregated as lived experience. This does not mean that morality is universal; instead, it is contingent upon the material resource framework and the evolutionary stage of consciousness as constituted in the framework. In that sense, assuming the phenomenal properties of subatomic particles get recycled/superimposed/entangled between the superverse and its multiverses as I am positing here, morality is an epiphenomenon of lived-experience and becomes an emergent property of the superverse and its multiverses, which constitute the laws platonic forms or concepts such as beauty, justice, egalitarianism, etc. of Haitian metaphysics that human reason, which are the recycled subatomic neuronal/chemical particles of the superverse and multiverse operating through DNA and its aggregation as the brain and mind perception, can reflect upon to constitute their beingin-the-world practical consciousness in relation to the language, ideology, etc., i.e., social class language game, of those who precedes individual existence. Each multi world has its own practical activity or consciousness, based on the material structure of its resource framework, by which we ought to recursively organize and reproduce our being in them. However, the evolutionary nature of both our being-in-the-material resource framework and the material resource framework itself is limited by the stage of development of our embodied practical consciousness in them.
In this sense, morality in Mocombe's theory of phenomenological structuralism is both naturalistic and emotive.

\section{References}

1. Althusser, Louis (2001) Lenin and philosophy and other essays. Monthly Review Press, New York, USA.

2. Althusser, Louis E (1970) Reading capital (Ben Brewster, Trans), London.

3. Balibar, E, Immanuel W (1991) Race, nation, class: Ambiguous identities. Verso, London.

4. Buck M, Susan (2009) Hegel, Haiti, and universal history. University of Pittsburgh Press, Pittsburgh, USA.

5. Cohen J (2002) Protestantism and capitalism: the mechanisms of influence. Aldine de Gruyter, New York, USA.

6. Crothers, Charles (2003) Technical advances in general sociological theory: the potential contribution of post-structurationist sociology. Perspectives 26(3): 3-6.

7. Dahrendorf R (1959) Class and class conflict in industrial society. Stanford, Stanford University Press, California, USA.

8. Douglas M (1986) How Institutions think. Syracuse University Press, New York. In: Du Bois, Laurent (Eds.), Avengers of the new world, Harvard University Press, Massachusetts, USA.

9. Fraser N (1997) Justice interruptus: Critical reflections on the post socialist condition. Routledge, New York, USA.

10. Hameroff, Stuart, Roger P (2014) Consciousness in the Universe: A review of the orch OR theory. Physics of Life Reviews, 11: 39-78.

11. Holloway, Joseph E (1990) Africanisms in American culture. Bloomington and Indianapolis: Indiana University Press, India.

12. Holloway, Joseph E (1990) The origins of African American culture. In: Joseph Holloway (Eds.), Africanisms in American culture (19-33). Bloomington and Indianapolis: Indiana University Press, India.

13. Horkheimer M, Theodor A (2000) Dialectic of enlightenment john cumming, trans. Continuum, New York, USA.

14. Hudson, Kenneth, Andrea C (2005) The dark side of the protestant ethic: A comparative analysis of welfare reform. Sociological Theory 23(1): $1-24$.

15. James, CLR (1986) The black jacobins: Toussaint L' ouverture and the san domingo revolution. Vintage Karenga, Maulana. Introduction to Black Studies. The University of Sankore Press, California, USA.

16. Kellner, Douglas (2002) Theorizing globalization. Sociological Theory 20(3): 285- 305.

17. Kurtz, Lester R (2007) Gods in the global village: The world's religions in sociological perspective. Sage Publications, California, USA.

18. Lukács, Georg (1971) History and class consciousness: Studies in marxist dialectics rodney Livingstone, Trans. Cambridge, The MIT Press, Massachusetts, USA.

19. Lukács, Georg (2000) A Defense of history and class consciousness: Tailism and the dialectic (Esther Leslie, Trans.). London \& New York, Verso, USA.

20. Marcuse, Herbert (1964) One-dimensional man. Beacon Press, Boston, USA.

21. Marcuse, Herbert (1974) Eros and civilization: A philosophical inquiry into Freud. Beacon Press, Boston, USA.

22. Marx, Karl, Friedrich E (1964) The communist manifesto. Penguin Books, London, England.

23. Marx, Karl (1992) Capital: A critique of political economy Samuel Moore and Edward Aveling, Trans International Publishers, New York, USA. 
24. Marx, Karl (1998) The German ideology. Prometheus books, New York, USA.

25. McMichael, Philip (2008) Development and social change: A global perspective. Sage Publications, Los Angeles, California, USA.

26. Mocombe, Paul C (2019) The theory of phenomenological structuralism. Newcastle upon Tyne, Cambridge Scholars Publishing, UK.

27. Mocombe, Paul C (2016) The vodou ethic and the spirit of communism: The practical consciousness of the African people of Haiti. University Press of America, Maryland, USA.

28. Mocombe, Paul C (2009) The soul-less souls of black folk: A sociological reconsideration of black consciousness as du boisian double consciousness. University Press of America, Maryland, USA.

29. Ortner, Sherry (1984) Theory in anthropology since the sixties. Comparative Studies in Society and History 26: 126-66.

30. Patterson, Orlando (1982) Slavery and social death: A comparative study. Harvard University Press, Cambridge, Massachusetts, USA.
31. Ramsey, Kate (2011) The spirits and the law: Vodou and power in haiti. University of Chicago Press, Chicago, USA.

32. Rubin, Vera (1960) Caribbean studies: A Symposium. Seattle: University of Washington Press, USA.

33. Sklair, Leslie (1995) Sociology of the global system. Baltimore: Westview Press, USA.

34. Smith MG (1960) The African heritage in the caribbean. In: Vera Rubin (Eds), Caribbean Studies: A symposium. Seattle: University of Washington Press, USA, pp. 34-46.

35. Wallerstein, Immanuel (1982) The rise and future demise of the world capitalist system: Concepts for comparative analysis. In: Hamza Alavi, Teodor Shanin (Eds), Introduction to the sociology of developing societies. Monthly Review Press, New York, USA, pp. 29-53.

36. Weber, Max (1958) The protestant ethic and the spirit of capitalism (Talcott Parsons, Trans). Charles Scribner's Sons, New York, USA.

For possible submissions Click below: 